\title{
Controlling and Calibration of Psychrometric Room
}

\author{
Kasuba Sainath \\ Associate Professor, MED, Sreyas Institute of Engineering \&amp;Technology,Nagole,Hyderabad,Telangana State \\ India 500068 \\ Akshay Hemanth \\ Student,I yr M.Sc, Chemical and Energy Engineering,OTTO-VON-Guericke-University MAGDEBURG GERMANY \\ T. Kishen Kumar Reddy \\ Professor of Mechanical Engg.\&amp;Former Rector Jawaharlal Nehru Tech. University Hyderabad,Telanga \\ state500 085, INDIA,Mobile No:9885196843 \\ Suresh Akella \\ Principal \&amp; Professor in MED,AuthorSreyas Institute of Engineering \&amp;Technology, Nagole \\ ,Hyderabad,Telangana State India500068
}

\begin{abstract}
The project reports on the performance of Air Conditioners at difsferent test standards. The future design of air conditioners is being driven by (a) improved energy efficiency standards and (b) the need to eliminate ozone-depleting working fluids. Various agencies of national and international continue to impose more stringent requirements for energy efficiency. In addition, consumer Interest to select unit with lower operating costs further drives the need for improved performance. The main objective of this project is to know the standards which will maintain the standard conditions in psychrometric room (AC test room), which have been constructed to test the air conditioners and to establish different test procedures. The test that should be performed in Air conditioner test room are cooling capacity test. The main objective of the Fabricators \& Assemblers are to produce the systems according to requirements of costumers which can give more Output Like cooling effect, low power consumption, high ERR to with stand competition in the market. In every country, the Fabricators follow some standards according to the climatic conditions to test the appliances.
\end{abstract}

Keywords: Psychrometric room, COP cooling test, power consumption test, effect on climatic conditions, CFM.

\section{INTRODUCTION}

In our country lies in the hot zone therefore the comfort air conditioning has always been felt to be a necessity for mankind. To achieve Human comfort, heat is extracted from the comfort region and transferred to the environment, which is at a higher temperature. This is done with the help of refrigeration. Though there are many methods to achieve cooling, one process that is mostly applied in refrigeration equipment and its application is vapor compression cycle is in AC units, the more commonly used one is room air conditioners, and then comes the systems which are used for higher tonnages . The invention of Air Conditioning as one of Refrigeration application by WH carrier in developed countries in earlier 19th century, there has been a drastic change in the methods and process used in manufacturing air-conditioning equipment but there is no change in the principle i.e. vapour compression system used in the cycle.

Air conditioners are to be tested by the Psychometric method in the absence of balanced room calorimeter in the country. The test setup consists of two rooms known as cold room (room side) and hot room (outside). The room air conditioner under test is mounted in the opening of the wall common to both cold and hot rooms. The particulars of room sizes, construction, testing equipment, instruments are follows.

The equipment's associated with the air conditioner test room as follows: 
- Panel boards

- Split Ac Indoor Unit Installation

- Split Ac outdoor Unit Installation

- Packaged Air Conditioners

- Humidifiers

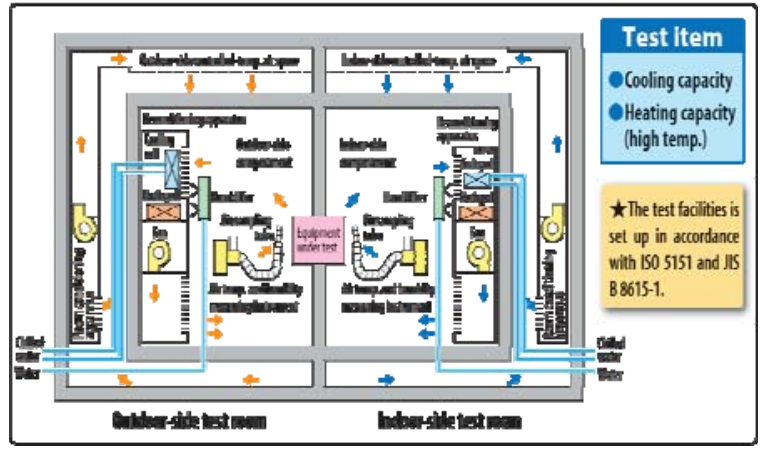

Fig.1: Psychometric laboratory view

- $\quad$ DBT- DRY BULB TEMPERATURE

- WBT-WET BULB TEMPERATURE

- DC- DIMMER CENTER

- $\quad$ DR- DIMMER RIGHT

- DL-DIMMER LEFT

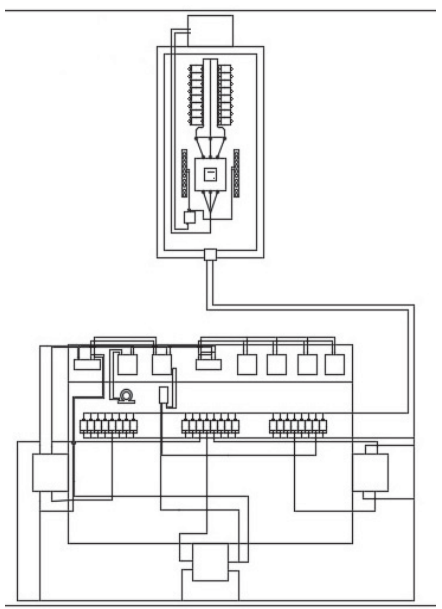

- Code Tester

- Temperature measuring instrument

- Heaters

- Sampling device

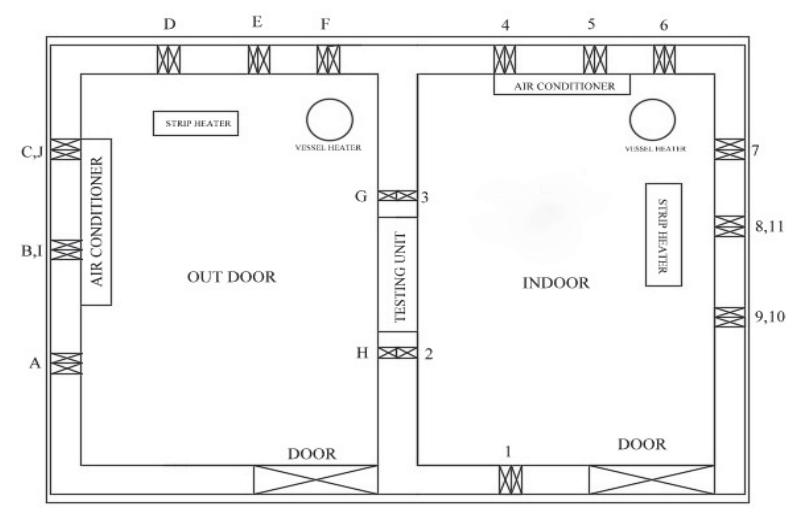

Fig.2: 2-D VIEW OF PSYCHROMETRIC ROOM 1 
Bill of Material for Test Room

\begin{tabular}{|l|l|l|l|}
\hline S.No & Material used & Qty & Make \\
\hline 1 & Plaster Of Paris & - & - \\
\hline 2 & Switch Boards & 30 & PVC \\
\hline 3 & Insulating Material & - & Thermocol \\
\hline
\end{tabular}

\section{COMPONENTS OF PSYCHROMETRIC ROOM}

\subsection{Control Panel:}

A control panel is a flat, often vertical, area where control or monitoring instruments are displayed. It is a panel that contains fuses and dimmers (here) for controlling the electrical devices which are inside the room.

They are Interested in factories to monitor and control machines or production lines and in places such as nuclear power generating units, Big Submarines, Aero planes and Super computers. Older control panels are most often well equipped with Automation and analog instruments, whereas nowadays in many cases touch screens are used for monitoring and control purposes

Bill Of Materials of Control Panel:

\begin{tabular}{|l|l|l|l|}
\hline S.No & Material used & Qty & Make \\
\hline 1 & M.S Angle Rods & & M.S \\
\hline 2 & Wooden Plank & 2 & - \\
\hline 3 & Dimmer stat & 3 & - \\
\hline 4 & Voltmeter & 1 & - \\
\hline 5 & Ammeter & 1 & - \\
\hline 6 & Wattmeter & 1 & - \\
\hline 7 & Frequency Indicator & 1 & - \\
\hline 8 & Temperature Indicators & 4 & - \\
\hline 9 & MCB & 24 & Legrand \\
\hline 10 & Wiring & & Finolex \\
\hline 11 & Bolts \& Nuts & 40 & C.I \\
\hline
\end{tabular}

Fig.4: Control Panel 1

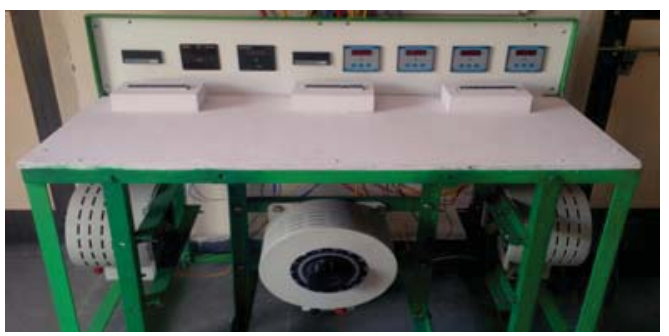

\section{RESULTS}

\begin{tabular}{|l|l|l|l|l|l|}
\hline s.no & $\begin{array}{l}\text { Time } \\
\text { (mins) }\end{array}$ & Volts & $\begin{array}{l}\text { Dry bulb } \\
\text { temp }\end{array}$ & $\begin{array}{l}\text { Wet bulb } \\
\text { temp }\end{array}$ & $\begin{array}{l}\text { Relative } \\
\text { humidity }\end{array}$ \\
\hline 1 & 0 & 0 & 32.7 & 27.7 & $74 \%$ \\
\hline 2 & 5 & 160 & 36.2 & 33.4 & $84 \%$ \\
\hline 3 & 10 & 170 & 39.9 & 36.1 & $79 \%$ \\
\hline 4 & 15 & 180 & 43.1 & 38.6 & $78 \%$ \\
\hline 5 & 20 & 190 & 45.9 & 40.1 & $72 \%$ \\
\hline 6 & 25 & 200 & 48.1 & 43 & $77 \%$ \\
\hline 7 & 30 & 210 & 50.4 & 44.4 & $75 \%$ \\
\hline 8 & 35 & 220 & 52.2 & 45.1 & $70 \%$ \\
\hline 9 & 40 & 230 & 54.1 & 46.6 & $68 \%$ \\
\hline
\end{tabular}

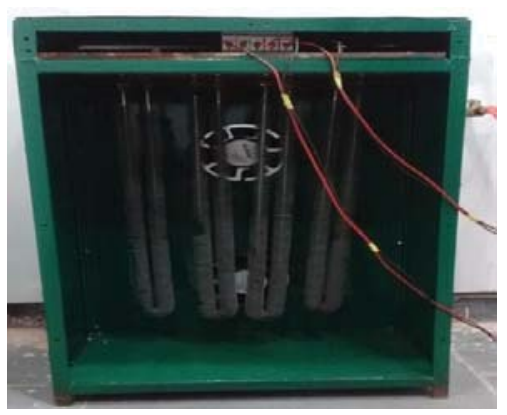


Table 2.1:-Thermocouple Readings

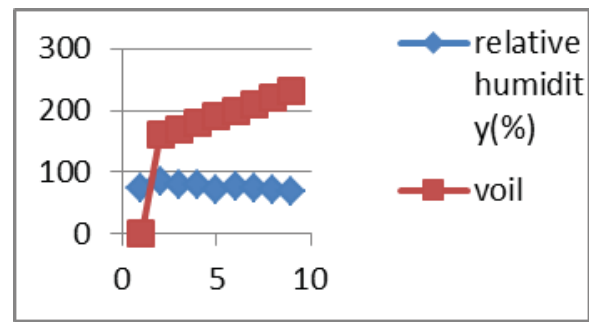

In the present work we have identified there are critical areas where all these conditions place a vital role in the present specified application, from the heating effect of strip heaters. The table 1 shows the thermocouples results the thermocouple are placed at the critical areas are identified as shown in the table.1.

The following results are explained in detail, with the results obtained by the thermo couples as follows below.

Table 5.2:- Relative Humidity vs Dry Bulb Temperature

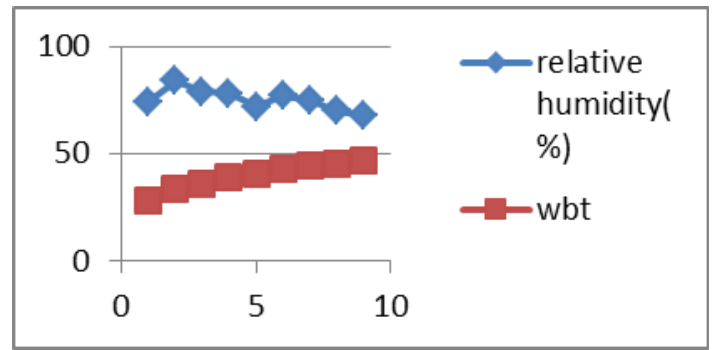

In adjacent figure shows graph of a relative humidity and wet bulb temperature. The values are taken at a nine conditions at various timings. At initial stage of a dbt,relative humidity is a value of a $74 \%$ and after a value of wbt is $36.2 * \mathrm{c}$ then relative humidity is $84 \%$.At a $39.9 * \mathrm{c}$ then relative humidity is $79 \%$.At a $38.6 * \mathrm{c}$ then relative humidity is $78 \%$. As so values came out.

Relative Humidity vs Volts

In Fig 5.3 shows graph of a relative humidity and wet bulb temperature. The values are taken at a nine conditions at various timings.At initial stage of a wbt,relative humidity is a value of a $74 \%$ and after a value of wbt is $33.4 * \mathrm{c}$ then relative humidity is $84 \%$.At a $36.1{ }^{*} \mathrm{c}$ then relative humidity is $79 \%$.At a $38.6 * \mathrm{c}$ then relative humidity is $78 \%$.As so values came out.

\section{HUMIDIFIER}

A humidifier is a component that increases moisture in a single tested room or an entire building. In Domestic, point-of-use humidifiers are commonly used to increase the moisture in single tested room, while whole-house remained hot The study of HVAC system, provide humidity to the entire house. Medical ventilators often include humidifiers for increased patient comfort. The Large humidifiers are used in commercial, institutional, or industrial contexts, often as part of a larger HVAC system. 
OBSERVATION:

\begin{tabular}{|l|l|l|l|l|l|}
\hline $\begin{array}{l}\text { S.N } \\
\text { O }\end{array}$ & Time & Voltage & $\begin{array}{l}\text { Dry Bulb } \\
\text { Temperature }\end{array}$ & $\begin{array}{l}\text { Wet Bulb } \\
\text { temperature }\end{array}$ & $\begin{array}{l}\text { Relative } \\
\text { Humidity }\end{array}$ \\
\hline 1 & 0 & 0 & 35.2 & 29.6 & 66.1 \\
\hline 2 & 5 & 160 & 35.1 & 29.9 & 68.2 \\
\hline 3 & 10 & 170 & 35.0 & 29.9 & 68.7 \\
\hline 4 & 15 & 180 & 35.2 & 30.3 & 69.9 \\
\hline 5 & 20 & 190 & 35.5 & 30.8 & 71.2 \\
\hline 6 & 25 & 200 & 35.9 & 31. & 71.9 \\
\hline 7 & 30 & 210 & 36.2 & 32.0 & 74.3 \\
\hline 8 & 35 & 220 & 37.0 & 32.9 & 75.1 \\
\hline 9 & 40 & 230 & 37.7 & 33.8 & 76.5 \\
\hline 10 & 45 & 240 & 38.5 & 35.0 & 79.9 \\
\hline
\end{tabular}

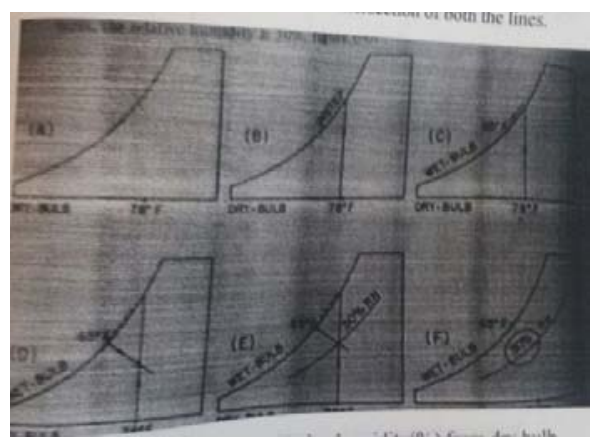

\section{TESTING \& OPTIMIZATION OF WINDOW AC AT TECUMSEH}

Majorly in Domestic purpose we have 2 types of Air Conditioners.

1. WINDOW A C OR UNITARY A C.

2. SPLIT A C.

The main difference in WINDOW and SPLIT A.C is that High pressure and low pressure side are located in one single unit called as WINDOW.AC, and these are located in separate arrangement called as SPLIT.AC. These two types of A.C's are explained below.

CAPACITY CALCULATION OF AIR CONDITIONER:

First we optimize the Test unit according ISO-5151 Test standard @T1 condition i.e,

\begin{tabular}{|l|l|l|}
\hline & \multicolumn{1}{|c|}{ DBT } & WBT \\
\hline Indoor Room & 27 & 19 \\
\hline Outdoor Room & 35 & 24 \\
\hline
\end{tabular}

We need to maintain accurate Dry bulb and Wet bulb temperatures at both Indoor and Out door Rooms to get exact cooling capacity. We can take the readings after continuous running of 1 hour period at balanced ambient only.

We can calculate the cooling capacity by using psychometric way (by using psychometric chart).

To be find:- Capacity:-? \& EER:-?. Formulae: - $\mathrm{Q}=\mathrm{m}(\mathrm{h} 1-\mathrm{h} 2)$.

$\mathrm{Q}=$ Cooling capacity. $\quad \mathrm{h}=$ Enthalpy $\mathrm{m}=$ mass flow rate.

For example:- Consider 1.5 ton SPLIT AC unit running at ISO5151 Standard. i.e
D.B.T $=26.92^{\circ} \mathrm{C}$
W.B.T $=18.7^{\circ} \mathrm{c}$
Then $\mathrm{h} 1=63 \mathrm{kj} / \mathrm{kg}$. (Considered from psychometric chart)

We all know that we take the coincidence point on enthalpy line. Next we had taken the D.B.T \& W.B.T at air out (grill) temperature. i.e
D.B.T $=16^{\circ} \mathrm{c}$
W.B.T $=13.5^{\circ} \mathrm{c}$
$\mathrm{h} 2=32 \mathrm{kj} / \mathrm{kg}$.

Mass flow rate $=$ Density X C.F.M. $=0.01223 \mathrm{~kg} / \mathrm{m} 3 \times 1231.78 \mathrm{~m} 3 / \mathrm{hr}$ (density from Psychometric chart)

Capacity $=0.01223 \times 1231.78 \times(63-32)=16827 \mathrm{btu} / \mathrm{hr}$.

\section{TESTING OF WINDOW AC AT TECUMSEH TESTING ROOM}


For calculation of any values, generally we take a reference to calculate. So here we take the Tecumseh testing room for calibration of our testing specimen, and then calculate the calibration factor and then multiply it with the calculated values of our specimens. Below here are the calculated values at Tecumseh:

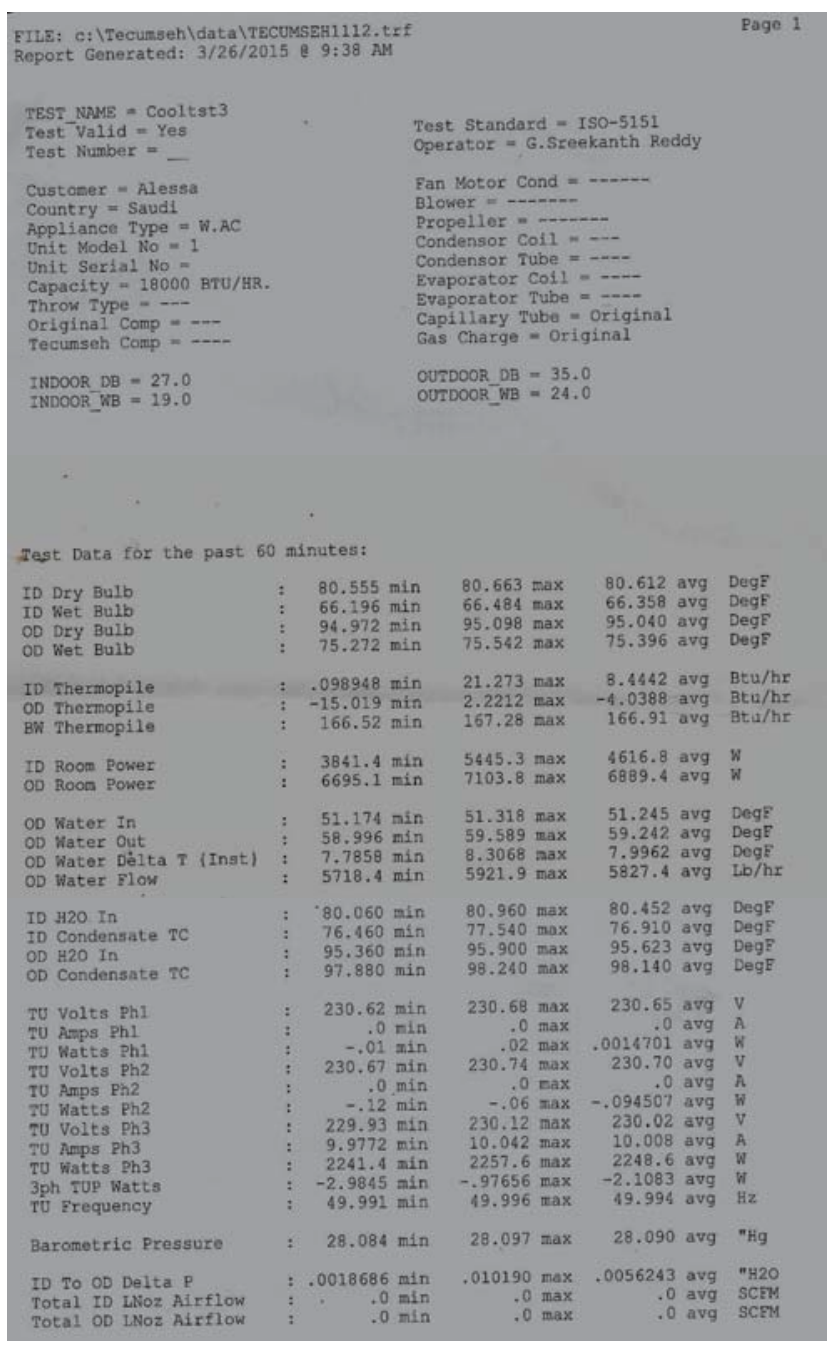
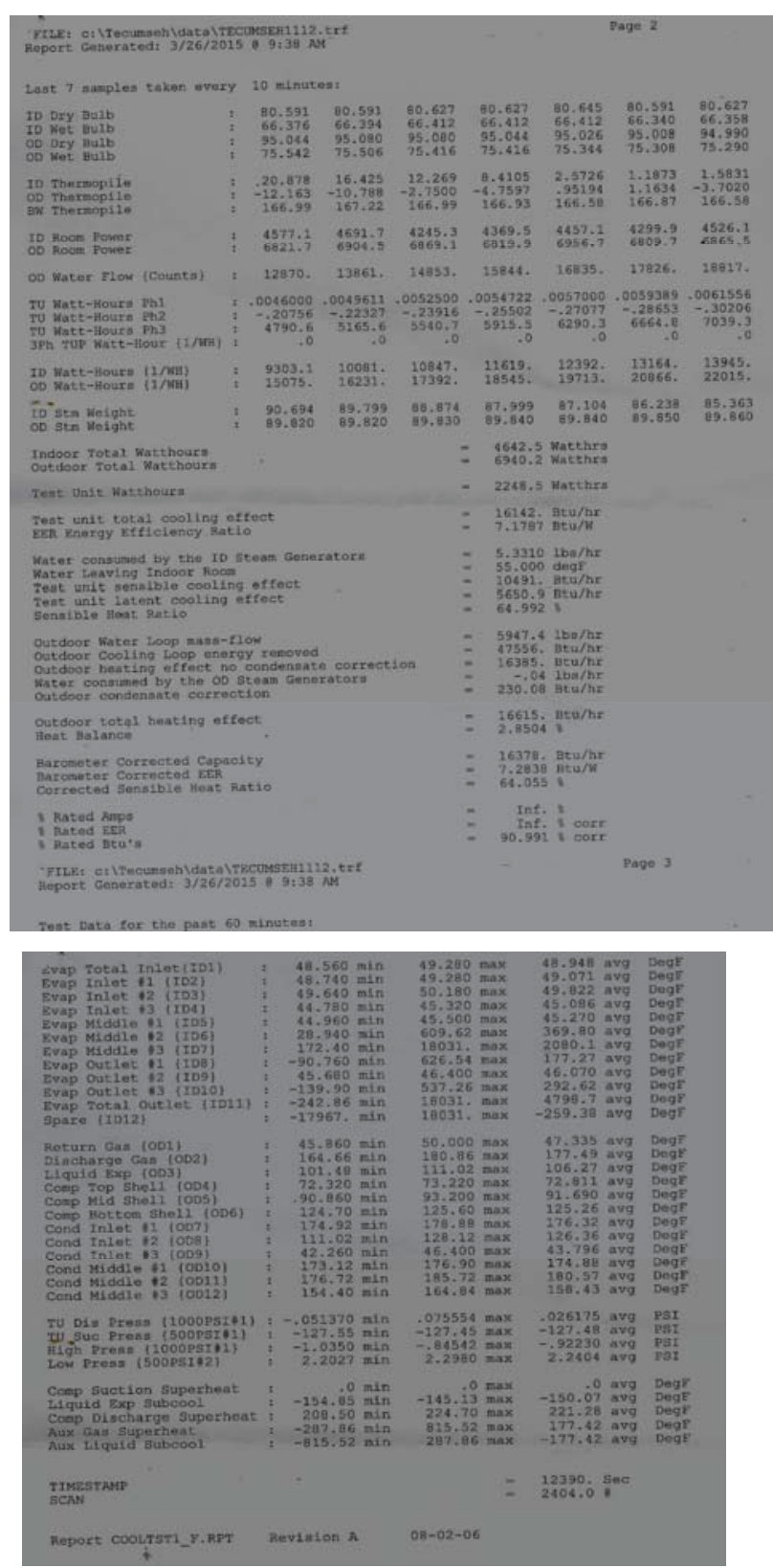

\section{EXPERIMENTAL ANALYSIS OF PSYCHROMETRIC ROOM}

The experimental test had been conducted with calorimeter test for air conditioning and vapor compression cycle performance test, the calorimeter has the facility to conduct from small air conditioners unit to large chillers. 


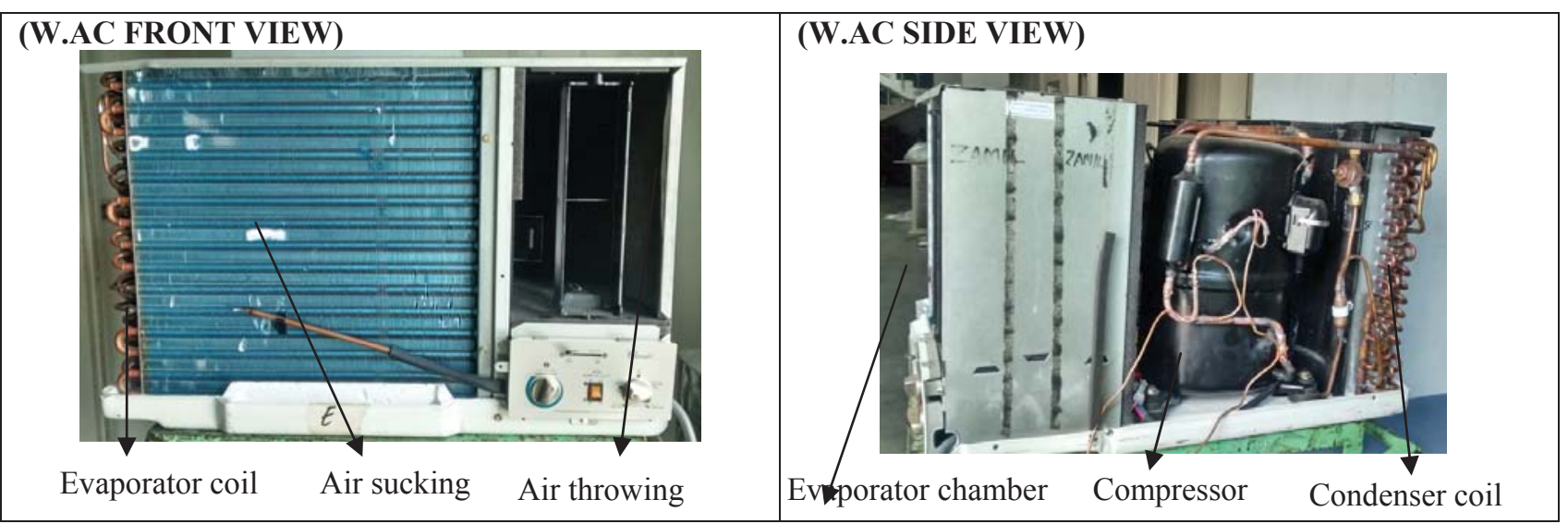

OBSERVATIONS MADE WITH PSYCHROMETRIC ROOM

\begin{tabular}{|l|l|l|l|}
\hline & $\mathrm{T}_{1}$ & $\mathrm{~T}_{2}$ & $\mathrm{~T}_{3}$ \\
\hline Receiver gas & 8.3 & 9.3 & 12.1 \\
\hline Discharge gas & 69.2 & 65.7 & 76.0 \\
\hline Liquid line & 45.9 & 44.3 & 48.1 \\
\hline Shell top & 19.0 & 20.4 & 24.2 \\
\hline Shell bottom & 50.8 & 43 & 52.5 \\
\hline Evaporator entry & 18.9 & 19.7 & 21.4 \\
\hline Evaporator exit & 6 & 34 & 9.9 \\
\hline Evaporator middle & 10 & 11.1 & 13.9 \\
\hline Ambient & 34.3 & 34 & 37.3 \\
\hline Condenser middle & 56.4 & 56.4 & 60.7 \\
\hline
\end{tabular}

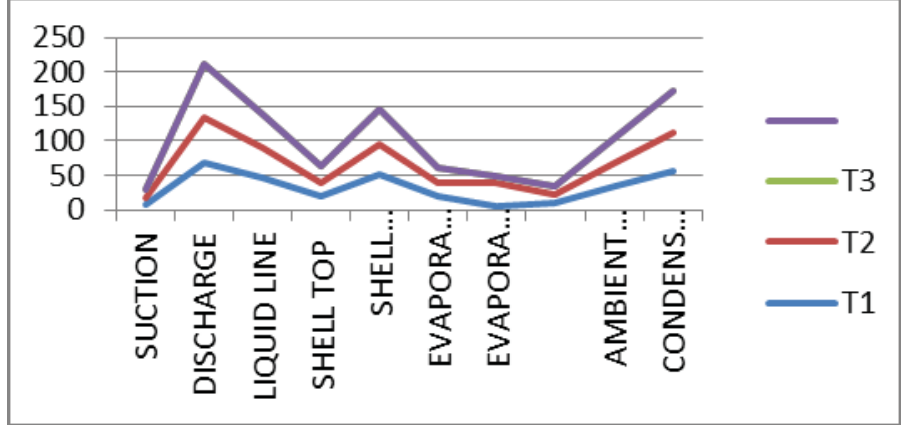

\subsection{Cooling Capacity conditions:}

Area, $\mathrm{Ai}=((22 / 7 * 4) * \operatorname{SQRT}(48.66 / 1000))+((22 / 7 * 4) * \operatorname{SQRT}(99.43 / 1000))=0.00962 \mathrm{~m} 2$ Cubic flow per minute, $\mathrm{Cfm}=\mathrm{Ci} * \mathrm{Yi}^{*} \mathrm{Ai} * \mathrm{SQRT}\left((2 * \mathrm{Dp}) / \mathrm{D}_{\mathrm{le}}\right) * 3600 * 0.5885=0.985 * 0.998 * 0.00962 * \operatorname{SQRT}((2 * 445) / 1.2138) * 3600 * 0.5885$ $=542.56$ or 543

Volume flow rate, $\mathrm{Q}_{\mathrm{va}}=\mathrm{Cfm} / 2118.88=543 / 2118.88=0.2562 \mathrm{~m} 3 / \mathrm{sec}$

Enthalpy difference, $D_{h}=h_{e n}-h_{l e} \quad=48.53-30.60=17.93 \mathrm{kj} / \mathrm{kg}$

Mass flow rate, $\mathrm{Ma}=$ Volume flow rate $\left(\mathrm{Q}_{\mathrm{va}}\right) /$ Specific volume of leaving air $\left(\mathrm{V}_{\mathrm{le}}\right)=0.2562 / 0.8238=0.3109 \mathrm{~kg} / \mathrm{sec}$

Cooling capacity in KW = Mass flow rate $(\mathrm{Ma}) *$ Enthalpy difference $\left(\mathrm{D}_{\mathrm{h}}\right)=0.3109 * 17.93=5.5744 \mathrm{~kW}$

Cooling capacity in Btu/hr = cooling capacity in $\mathrm{kw}^{*} 3412.14=5.5744 * 3412.14=19020.75 \mathrm{Btu} / \mathrm{hr}$

Cooling capacity in TON of refrigeration $=$ cooling capacity in $\mathrm{kw} / 3.516=5.5744 / 3.516=1.58544$ Ton

Energy efficiency ratio,EER $=($ cooling capacity in Btu/hr $) /($ Input power in watts $)=19020 / 2240=8.491 \mathrm{Btu} / \mathrm{W}-\mathrm{hr}$

Therefore calibration factor for psychrometric room is 19020/21032.43 $=0.904$ Which is nothing but $\underline{\mathbf{1 . 0 9 6}}$

\subsection{COOLING CAPACITY CALCUALTIONS:-}

\section{FORMULAE FOR COOLING CAPACITY CALCULATIONS:}

Volume Flow rate of air $\mathrm{Qva}(\mathrm{m} 3 / \mathrm{sec})=\mathrm{Cfm} / 2118.88$

Enthalpy difference $\mathrm{Dh}=$ Enthalpy of moist air entering - Enthalpy of moist air leaving

Mass flow rate of air $\mathrm{Ma}(\mathrm{kg} / \mathrm{s})=$ Volume flow rate of air $/$ Specific volume of air

Cooling capacity in $\mathrm{KW}=$ Mass flow rate of air*Enthalpy difference

Cooling capacity in Btu/hr=Cooling capacity in $\mathrm{KW} * 3412.14$

Cooling capacity in Ton of refrigeration $=$ Cooling capacity in KW/3.5167

\section{CALCULATIONS}

Calculations at 35OC Ambient: Entering air conditions: DBT-27.11 OC, WBT-19.27 OC 
Saturation pr.at DBT, $\mathrm{Ps}=610.78 * \mathrm{EXP}(\mathrm{DBT} /(\mathrm{DBT}+238.3) * 17.2694) / 1000$

$=610.78 * \operatorname{EXP}(27.11 /(27.11+238.3) * 17.2694) / 1000=3.5642 \mathrm{kpa}$

Saturation pr. At WBT, $\mathrm{Pl}=610.78 * \operatorname{EXP}(\mathrm{WBT} /(\mathrm{WBT}+238.3) * 17.2694) / 1000$

$=610.78 * \operatorname{EXP}(19.27 /(19.27+238.3) * 17.2694) / 1000=2.2232 \mathrm{kpa}$

Actual vapour pressure, $1 \mathrm{lPv}=\mathrm{Pv}-(((\mathrm{Pt}-\mathrm{Pv}) *(\mathrm{DBT}-\mathrm{WBT}) *(1.8)) /(2800-1.3((1.8 * \mathrm{DBT})+32))$

$=2.2232-(((101.325-2.2232) *(27.11-19.27) *(1.8)) /(2800-1.3((1.8 * 27.11)+32))=1.7042 \mathrm{kpa}$

Humidity ratio, $\mathrm{W}=0.622 *(\mathrm{PV} /(\mathrm{Pt}-\mathrm{Pv}))=0.622 *(1.7042 /(101.325-1.7042))=0.01064$

Enthalpy of moist air, hen $=(1.005 * \mathrm{DBT})+\left(\mathrm{W} *\left(2500+\left(1.88^{*} \mathrm{DBT}\right)\right)\right)$

$=(1.005 * 27.11)+(0.01064 *(2500+(1.88 * 27.11)))=54.3878 \mathrm{kj} / \mathrm{kg}$

Specific volume of air, Ven $=(287.3 *(273+\mathrm{DBT})) /((\mathrm{Pt}-\mathrm{Pv}) * 1000)$

$=(287.3 *(273+27.11)) /((101.325-1.7042) * 1000)=0.8654 \mathrm{~m} 3 / \mathrm{kg}$

Density of moist air, Den $=1 / \mathrm{Ven}=1 / 0.8653=1.1556 \mathrm{~kg} / \mathrm{m} 3$

Leaving air conditions: DBT-13.78oC,WBT-12.25oC

Saturation pr. At DBT,

$\mathrm{Ps}=610.78 * \mathrm{EXP}(\mathrm{DBT} /(\mathrm{DBT}+238.3) * 17.2694) / 1000$

$=610.78 * \operatorname{EXP}(13.78 /(13.78+238.3) * 17.2694) / 1000=1.5699 \mathrm{kpa}$

Saturation pr. At WBT,

$\mathrm{P}=610.78 * \operatorname{EXP}(\mathrm{WBT} /(\mathrm{WBT}+238.3) * 17.2694) / 1000$

$=610.78 * \operatorname{EXP}(12.25 /(12.25+238.3) * 17.2694) / 1000=1.4209 \mathrm{kpa} 40$

Actual vapour pressure, 1

$\mathrm{Pv}=\mathrm{Pv}-(((\mathrm{Pt}-\mathrm{Pv}) *(\mathrm{DBT}-\mathrm{WBT}) *(1.8)) /(2800-1.3((1.8 * \mathrm{DBT})+32))$

$=1.4209-(((101.325-1.4209) *(13.78-12.25) *(1.8)) /(28001.3((1.8 * 13.78)+32))=1.3199 \mathrm{kpa}$

Humidity ratio, $\mathrm{W}=0.622 *(\mathrm{Pv} /(\mathrm{Pt}-\mathrm{Pv}))=0.622 *(1.3199 /(101.325-1.3199))=0.0082$

Enthalpy of moist air, hle $=(1.005 * \mathrm{DBT})+\left(\mathrm{W}^{*}(2500+(1.88 * \mathrm{DBT}))\right)$

$=(1.005 * 13.78)+(0.0082 *(2500+(1.88 * 13.78)))=34.5613 \mathrm{KJ} / \mathrm{KG}$

Specific volume of air, Vle $=(287.3 *(273+\mathrm{DBT})) /((\mathrm{Pt}-\mathrm{Pv}) * 1000)$

$=(287.3 *(273+13.78)) /((101.325-1.3199) * 1000)=0.8238 \mathrm{~m} 3 / \mathrm{kg}$

Density of moist air, Dle $=1 / \mathrm{Vle}=1 / 0.8238=1.2138 \mathrm{~kg} / \mathrm{m} 3$

\section{3: Calculations for cooling capacity:}

Area, $\mathrm{Ai}=\boldsymbol{A}=\mathrm{F}^{\mathbf{2}}=0.00962 \mathrm{~m} 2 \mathrm{Cubic}$ flow per minute,

$\mathrm{Cfm}=\mathrm{Ci} * \mathrm{Yi} * \mathrm{Ai} * \mathrm{SQRT} \quad\left((2 * \mathrm{Dp}) / \mathrm{D}_{\mathrm{le}}\right) * 3600 * 0.5885=0.985 * 0.998 * 0.00962 * \mathrm{SQRT} \quad((2 * 445) / 1.2138) * 3600 *$

$0.5885=203.826$ OR 204

Volume flow rate, $\mathrm{Qva}=\mathrm{Cfm} / 2118.88 \quad=543 / 2118.88=0.096 \mathrm{~m} 3 / \mathrm{sec}$

Enthalpy difference, $\mathrm{D}_{\mathrm{h}}=\mathrm{h}_{\mathrm{en}}-\mathrm{h}_{\mathrm{le}}=54.3878-34.5613=19.8265 \mathrm{kj} / \mathrm{kg}$

Mass flow rate, $\mathrm{Ma}=$ Volume flow rate $\left(\mathrm{Q}_{\mathrm{va}}\right) /$ Specific volume of leaving air $\left(\mathrm{V}_{\mathrm{le}}\right)=0.096 / 0.8238=0.117 \mathrm{~kg} / \mathrm{sec}$

Cooling capacity in $\mathrm{KW}=$ Mass flow rate $(\mathrm{Ma}) *$ Enthalpy difference $\left(\mathrm{D}_{\mathrm{h}}\right)=0.3109 * 19.8265=2.314 \mathrm{kw}$

Cooling capacity in Btu/hr = cooling capacity in $\mathrm{kw}^{*} 3412.14=2.314 * 3412.14=7897.023 \mathrm{Btu} / \mathrm{hr}$

Cooling capacity in TON of refrigeration $=$ cooling capacity in $\mathrm{kw} / 3.516=2.314 / 3.516=0.65$ Ton

Energy efficiency ratio, EER $=($ cooling capacity in Btu/hr $) /($ Input power in watts $)=7897.023 / 2240=3.52 \mathrm{Btu} / \mathrm{W}-\mathrm{hr}$

\section{CONCLUSION}

- Every product that is Fabricated is to be tested to know how it works and up to what level it can satisfy the costumers requirement.

- The main objective of this project is testing a c appliance according to different standards by maintaining different combinations of Ambient conditions in Air conditioner test room. 
- The testing includes cooling capacity test, power consumption test.

- From capacity test, cooling capacity of system at different temperatures is known. Cooling capacity test is done on AC appliance.

- The specification given by manufacturer for cooling capacity of Air conditioner at $35^{\circ} \mathrm{C}$ ambient is 21200 $\mathrm{Btu} / \mathrm{hr}$, by cooling capacity test in the a c test room it is found that its capacity is lower by $1.4 \%$ i.e. 20908 $\mathrm{Btu} / \mathrm{hr}$. at $35^{\circ} \mathrm{C}$ room temp.

- Similarly cooling capacity of $\mathrm{AC}$ at $46^{\circ} \mathrm{C}$ and $54^{\circ} \mathrm{C}$ ambient is found to be $19332 \mathrm{Btu} / \mathrm{hr}$. and $5582 \mathrm{Btu} / \mathrm{hr}$.

- Power consumption test is done on air conditioner and found that it consumes when operated for $24 \mathrm{hrs}, 16.5 \mathrm{Kw} / \mathrm{hr}$ units power i.e. $0.687 \mathrm{kw} / \mathrm{hr}$. at $35^{\circ} \mathrm{C}$ Ambient.

- At $46^{\circ} \mathrm{C}$ Ambient it is found to at it consumes $24.5 \mathrm{Kw} / \mathrm{hr}$ units of power i.e. $1.021 \mathrm{kw} / \mathrm{hr}$. in A C test room.

- The various factors observed amidst the testing were, amount of change of refrigerant, pressure drop, suction and discharge pressures, power consumption etc. From these work different procedures for testing AC s are established.

- The test results will give Database to the customers and fabricators. Useful data is for the air conditioning engineers.

\section{FUTURE SCOPE}

Because of the variations in the atmosphere due to many things like pollution green house effect, there is a gradually rise in increase of temperature because of which the demand of air conditioners has been increased. So to provide a efficient and less power consumable air conditioners to the people we have to test the air conditioners and know the flaws in it and rectify it we use one of the testing methods as "PSYCHROMETRIC ROOM".

By this method we can rectify flaws and increase the efficiency by which we have a lot of future and a vast scope to this. In this way we can conclude that it has a great future and scope.

\section{REFERENCES}

[1] Akintunde, M.A. 2004b. Experimental Investigation of The performance of VaporCompression Refrigeration Systems. Federal University of Technology, Akure, Nigeria

[2] American Society Heating Refrigeration and Air Conditioning. ASHRAE Hand Book. 2001

[3] Wernick, B.J. "Effectiveness method", RACA journal 2004.

[4] C.P Arora, Refrigeration and Air conditioning. TataMcGrawHillBookCompany

[5] Stoecker, W.F. and Jones J.W. (1982), Refrigeration \& Air Conditioning. McGraw-Hill BookCompany, Singapore

[6] Analytical expressions for optimum flow rates in evaporators and condensers of heat pumpingsystems International Refrigeration, Volume 33, Issue 7, November 2010,Pages 1211-1220 Granryd, E.

[7] Yumrutas R, kunduz M, Kanoglu M. Exergy analysis of vapor compression refrigerationsystems. $\quad$ Exergy, An international journal2002;2(4);26672.

[8] Dr.S.S. Banwait and Dr.S.C. Laroiya, "Properties of refrigerant and psychometric tablesand charts

[9] "Technical Manual Air-conditioning application, Tecumseh". Tecumseh Products India Pvt.Ltd., Hyderabad.

[10] Calorimeter Test Facility Lab manual (CTFLM) Tecumseh Products India Pvt. Ltd.

[11] Eckert, E.R.G.; Goldstein, R.J.; Ibele, W.E.; Patankar, S.V.; Simon, T.W.; Strykowski, P.J.;Tamma, K.K.; Kuehn, T.H.; Bar-Cohen, A.; Heberlein, J.V.R.; (Sep 1997), Heat transfer--are view of 1994 literature, International Journal of Heat and Mass Transfer 40-16, 37293804

[12] Kapil Chopra, Dinesh Jain, Tushar Chandana and Anil Sharma, "Evaluation of Existing Cooling Systems for Reducing Cooling Power Consumption", International Journal of Mechanical Engineering \& Technology (IJMET), Volume 3, Issue 2, 2012, pp. 210 - 216,ISSN Print: 0976 - 6340, ISSN Online: 0976 - 6359. 